\title{
DATA DAN DESA: STUDI KEGAGALAN DATA DRIVEN POLICYMAKING DALAM GDSC DI BOJONEGORO 2014-2018
}

\author{
Addien Paramita Devina Nugraha ${ }^{1}$ \\ ${ }^{1}$ Ditjen Bina Administrasi Kewilayahan Kementerian Dalam Negeri \\ addiennugraha@yahoo.com
}

\begin{abstract}
This study attempts to analyzing data driven policymaking (DDPM) from different perspective by explaining the failure of Healthy and Smart Movement (Gerakan Desa Sehat dan Cerdas; hereafter GDSC) on implementing DDPM. The existing studies generally explain DDPM as an approach on policymaking which focus on the data utilization during the process, while this study will also consider the context in which power operate in data driven policymaking. Findings led to the conclusion that the utilization of data will not define a more rational policymaking process. Power plays an important role on policymaking process, and data still could not replace its role, even the policymaking mechanisms are changed to accommodate empirical facts drawn by the data.
\end{abstract}

Keywords: Data driven policymaking, policy making, rural development.

\section{PENDAHULUAN}

Pada tahun 2014, Bupati Bojonegoro saat itu, Suyoto, menginisiasi GDSC sebagai sebuah gerakan penerapan DDPM. Gerakan ini dilembagakan melalui Peraturan Bupati Bojonegoro Nomor 47 Tahun 2014 tentang GDSC. Melalui Perbup ini, masing-masing instansi pemerintah di Bojonegoro didorong menggunakan data GDSC dalam menentukan arah kebijakan pembangunan di desa. Tujuannya agar ada sinergitas pembangunan antarinstansi pemerintah dalam menjalankan pembangunan di desa. Dalam artikel "Kado Tahun Baru, Angka Kemiskinan di Bojonegoro Turun 0.26\%” (2017), mengenai hasil pelaksanaannya, Kepala Bidang Perekonomian Badan Perencanaan dan Pembangunan Daerah (Bappeda) Bojonegoro, Rahmat Junaidi, menyebut GDSC memiliki andil dalam menurunkan angka kemiskinan di Bojonegoro. Pada periode yang sama dengan tahun pelaksanaan GDSC, Bojonegoro memang mengalami banyak perubahan ke arah kemajuan. Angka kemiskinan terus menurun dibarengi dengan angka pertumbuhan ekonomi yang meningkat.

Meskipun demikian, hasil validasi terhadap data GDSC yang dilakukan oleh Bojonegoro Institute justru menunjukkan adanya ketidakserasian antardata sehingga kualitas datanya dianggap tidak mumpuni untuk digunakan dalam pembuatan kebijakan. Lebih lagi, pemanfaatan data GDSC pun tidak pernah terlaksana hingga GDSC berakhir pada 2018. Instansi di lingkungan Pemkab dan di desa tidak memanfaatkan data GDSC dalam proses pembuatan kebijakan, sehingga GDSC dianggap gagal dalam memenuhi tujuan pokok DDPM, yakni pemanfaatan data. Kegagalan ini dianalisis menggunakan dua perspektif yakni, bagaimana teknis penggunaan data dalam pembuatan kebijakan, sekaligus bagaimana proses pembuatan kebijakan publik menjadi arena beroperasinya kekuasaan aktor yang terlibat. Dalam GDSC, aktor ini adalah Suyoto sebagai bupati dan inisiator GDSC, SKPD Pemkab, pemerintah desa, serta pelaksana lain yang akan dijelaskan lebih dalam nantinya.

Studi ini meyakini ada kekuasaan aktor yang beroperasi dibalik pelaksanaan GDSC. Keyakinan ini dilatarbelakangi oleh kepemimpinan Suyoto sebagai faktor determinan dalam kelahiran sekaligus 
berakhirnya GDSC. GDSC terjadi karena inisiasi Suyoto. Di saat bersamaan, berakhirnya GDSC pada 2018 terjadi selepas pergantian kepemimpinan dari Bupati Suyoto ke Bupati Ana. Bupati Ana menganggap GDSC tidak memiliki ketetapan hukum yang jelas. Padahal GDSC telah resmi disahkan melalui Perbup Nomor 47 Tahun 2014 tentang GDSC. Hal ini menandai bahwa kepemimpinan Suyoto memainkan peranan penting dalam pelaksanaan GDSC. Tanpa Suyoto, GDSC diakhiri begitu saja tanpa dilanjutkan atau digantikan pada masa kepemimpinan Bupati Ana. Hal ini juga mengindikasikan bahwa GDSC bukan hanya gerakan biasa yang mendorong pelaksanaan DDPM di Bojonegoro, tapi juga harus dimaknai sebagai produk rezim Suyoto di masa kepemimpinannya sebagai Bupati Bojonegoro.

Berdasarkan latar belakang kasus di atas, pertanyaan penelitian yang berusaha dijawab penelitian ini adalah bagaimana penerapan data driven policymaking dalam GDSC di Kabupaten Bojonegoro pada tahun 2014 hingga 2018? Kedua, bagaimana kekuasaan beroperasi dalam penerapan GDSC di Kabupaten Bojonegoro pada tahun 2014 hingga 2018?

\section{Data Driven Policymaking dalam Studi Terdahulu}

Kegagalan GDSC dalam menerapkan DDPM menambah bukti baru kegagalan pemerintah dalam kasus serupa. Studi-studi serupa sebelumnya telah membahas penerapan DDPM oleh pemerintah cenderung gagal dibanding ketika diterapkan oleh sektor privat. Melalui studinya, McAfee dan Brynjolfsson (2018) menemukan bahwa penerapan DDPM di sektor privat menunjukkan tren positif. Penerapannya cenderung terus membawa peningkatan produktivitas perusahaan atau organisasi. Lebied (2017) dan Gabriel (2017) menjelaskan tentang apa yang dilakukan oleh sektor privat ketika mengimplementasi DDPM. Berdasarkan hasil temuan penelitiannya, sektor privat cenderung mengalami peningkatan produktivitas ketika menerapkan pendekatan DDPM untuk menentukan strategi marketing eksternal sekaligus strategi internal perusahaan.

Hasil yang berbanding terbalik justru ditemui dalam laporan IBM (2015), PBB (2014), Hulme (2018), dan Kindornay (2016). Masing-masing menemukan bahwa penerapan DDPM di instansi pemerintah cenderung gagal. Penyebabnya beragam, mulai karena pengelolaan data yang tidak tepat, penerima kebijakan adalah masyarakat luas dengan kompleksitas kebutuhan masing-masing, serta buruknya infrastruktur teknologi. Sementara Numanovic (2017) dan Nemani (2016) menunjukkan optimisme melalui studinya. Menurut keduanya, masih ada peluang bagi pemerintah bisa sukses menerapkan DDPM dengan syarat pemerintah sendiri yang harus mengumpulkan data secara langsung. Selain itu, pemerintah juga harus memiliki infrastruktur database yang tepat dan mumpuni untuk mengumpulkan sekaligus memproses data. Dari studi-studi terdahulu dapat dilihat bahwa pembahasan DDPM masih berkutat pada teknis penggunaan data dalam pembuatan kebijakan publik. Padahal, pembuatan kebijakan publik perlu juga dipahami sebagai arena beroperasinya kekuasaan.

\section{METODE PENELITIAN}

Studi ini menggunakan metode kualitatif dengan teknik pengumpulan data melalui studi pustaka, dokumentasi, serta wawancara. Wawancara dilakukan pada narasumber yang memiliki 
keterlibatan langsung maupun tidak langsung dalam pelaksanaan GDSC. Beberapa yang terlibat langsung karena kaitannya dengan tugas dan fungsinya antara lain, Bupati dan jajaran Satuan Kerja Perangkat Daerah (SKPD). Adapun SKPD yang berperan sebagai leading sector, yakni Badan Perencanaan dan Pembangunan Daerah, ada juga yang dilibatkan karena kemampuannya seperti Dinas Komunikasi dan Informatika untuk membantu pembangunan sistem IT keperluan GDSC. Sisanya menjalankan fungsi pengawasan dan evaluasi terhadap jalannya GDSC. Selain SKPD Pemkab, pemerintah desa atau kelurahan sejumlah 490 di wilayah Bojonegoro pun menjadi penanggungjawab kunci GDSC. Pihak eksternal pemerintah yang terlibat dalam GDSC adalah Kelompok Dasawisma di setiap desa dan LSM seperti Bojonegoro Institute. Keterlibatannya selain membantu teknis pelaksanaan di lapangan, juga turut mengawasi jalannya GDSC.

Pertanyaan yang diajukan dibuat dengan mengadaptasi model analisis evidence-based policy dari Smeru (2017). Ada beberapa hal yang akan berubah dalam sebuah organisasi ketika memutuskan untuk mengubah metodologi pembuatan kebijakannya, yakni (1) how priorities were made, (2) the supply and demand of evidence, dan (3) when difficult choices have to be made. Tiga hal ini akan menjadi bahan amatan untuk memahami bagaimana penggunaan data sekaligus bagaimana interaksi antaraktor yang terjadi di balik proses itu. Dengan memahami bagaimana data digunakan, maka dapat dipahami juga bagaimana pelaksanaan DDPM. Sementara, dengan memahami interaksi antaraktor di balik proses itu, akan dapat dipahami juga bagaimana kekuasaan beroperasi dalam GDSC. Namun penggunaan data dan interaksi antaraktor tidak akan dipahami sebagai dua hal yang terpisah. Sebab penggunaan data bisa jadi menjadi hasil interaksi antaraktor. Demikian dengan interaksi antaraktor bisa jadi dipengaruhi oleh penggunaan data.

\section{KERANGKA ANALISIS}

\section{Data Driven Policymaking: Sebuah Pendekatan Pembuatan Kebijakan Publik dan Arena}

\section{Beroperasinya Kekuasaan}

Perkembangan studi kebijakan publik turut diikuti oleh munculnya berbagai pendekatan pembuatan kebijakan publik yang baru. Pada 1990-an mulai muncul gerakan global yang mendorong penerapan pendekatan pembuatan kebijakan publik berbasis bukti (evidence-based policy). "Evidencebased policies is a decision-making process which combines deductive logic with statistical analysis to inform policy decision making" (Palangkaraya et al., 2012). Pendekatan ini menekankan pentingnya penggunaan bukti sebagai basis pembuatan keputusan dalam pembuatan kebijakan publik. Tujuan utamanya adalah mendorong pembuatan kebijakan publik yang rasional dibanding pembuatan kebijakan publik yang ideologis.

Pendekatan ini berangkat dari kritik pembuatan kebijakan yang semula cenderung ideologis dan irasional. Sebagai solusi dari kritik itu, pendekatan ini menawarkan pembuatan kebijakan publik yang berorientasi pada penyelesaian masalah. Bukti kebijakan memberikan informasi tentang masalah sekaligus memberikan alternatif kebijakan yang harus diambil untuk merespon masalah tersebut. 
Perkembangan teknologi membawa perkembangan juga pada pendekatan ini. Dalam perkembangan terbaru, pendekatan ini menemukan bentuk lain yakni DDPM atau pendekatan kebijakan berbasis data. Secara umum tujuan dan mekanisme pendekatan kebijakan berbasis data sama dengan pendekatan berbasis bukti. Tujuan kedua pendekatan ini sama, mengusahakan pembuatan kebijakan lebih rasional berdasarkan fakta empiris. Bedanya, fakta empiris dalam pendekatan berbasis data disajikan melalui data. Data yang digunakan bukan hanya data tunggal atau konvensional, melainkan umumnya berupa data granular atau data raksasa (big data). Perbedaan lainnya, jika evidence based policymaking semula cenderung dipahami sebagai proses pembuatan kebijakan yang linear dan teknokratis, DDPM justru telah dikerangkai sebagai new approach to governing oleh Essty dan Rushing (2007).

Penerapan pendekatan DDPM bukan hanya perkara teknis menjadikan data sebagai pemandu atau acuan dalam pembuatan kebijakan. Lebih dari itu, ada tiga kunci penerapan DDPM yang menunjukkan bahwa prosesnya merupakan proses yang kompleks, yakni (1) Collection and analysis of data to spotlight problem areas and potential solutions, (2) Development of quantifiable measures to asses policy performance and draw comparisons across similar circumtancers or peer groups so that best practices can be identified and expanded, (3) Public dissemination of data and metrics on policy results, so those outside government can hold public officials accountable for their performance.

Menggunakan model sistem politik David Easton (1956), dapat dijelaskan bahwa proses pembuatan kebijakan publik merupakan proses politik juga. Dibanding dimaknai sebagai proses yang terjadi untuk mengikuti teknis atau prosedur saja, pembuatan kebijakan publik lebih tepat dimaknai sebagai proses interaksi untuk merespon input, berikut kondisi lingkungan kebijakan. Pun dalam praktiknya, pembuatan kebijakan publik melibatkan berbagai aktor yang berinteraksi untuk mencapai sepakat berupa output kebijakan. Interaksi ini bisa terjadi dalam bentuk negosiasi atau tawar-menawar untuk mengakomodasi berbagai kepentingan.

Setiap bentuk interaksi itu tidak terjadi di ruang hampa. Interaksi apapun yang terjadi bertujuan mewujudkan ide atau aksi apapun yang ditentukan oleh siapa terlibat dan kekuasaan yang dimilikinya. Kekuasaan seseorang menentukan akses, posisi, dan pengaruhnya dalam interaksi tersebut. Menurut Santoso, Hanif, dan Gustomy (2004), masing-masing aktor senantiasa memperjuangkan kepentingannya sendiri dalam pembuatan kebijakan publik dengan cara mendayagunakan sumber kekuasaan miliknya. Maka, kebijakan publik disebutnya sebagai hasil dari fenomena multidimensional. Kebijakan publik bukan hanya produk administratif dan bukan juga hanya produk teknokratis, tetapi juga produk yang politis. Penggunaan data membuka banyak kemungkinan tentang terbentuknya interaksi yang terjalin antaraktor pembuatan kebijakan. Data bukan hanya bisa menjadi sumber pengetahuan, tetapi juga bisa menjadi sumber atau bentuk kekuasaan yang baru. Penggunaan data dapat memengaruhi interaksi dalam pembuatan kebijakan publik atau sebaliknya, interaksi dalam pembuatan kebijakan justru memengaruhi bagaimana data digunakan. 


\section{Rezim Data dan Kelahiran GDSC di Bojonegoro}

Pada 2017, dalam sebuah artikel "Bojonegoro: Kabupaten Pertama yang Menerapkan Big Data 2017” (2017), menyebut Bojonegoro sebagai Kabupaten pertama di Indonesia yang menerapkan big data. Menyusul pada 2018, sebuah artikel lain "Bojonegoro Taps into Big Data As Their Way Out of Poverty and Becomes Pioneer in Open Governance Partnership" (Putri, 2008), juga menceritakan perjalanan sukses Bojonegoro menerapkan big data untuk menangani kemiskinan. Di bagian pembuka artikel tersebut, penulisnya telah menyatakan keheranannya tentang Bojonegoro yang merupakan daerah miskin dan bukan kota besar, justru berhasil menerapkan big data untuk menangani kemiskinan. Memang, Bojonegoro sama sekali tidak identik dengan kabupaten yang pemerintahnya maju atau inovatif hingga mau bersusah payah menerapkan DDPM di saat pemerintah daerah lain di Indonesia atau dunia, masih asing dengan istilah itu.

Sebelum masa Indonesia merdeka, Bojonegoro telah disebut sebagai daerah dengan kemiskinan endemis karena usaha apapun yang dilakukan pemerintah kolonial saat itu untuk menyelesaikan masalah kemiskinan di sana tidak kunjung berhasil. Budaya birokrat di sana juga disebut bobrok, tidak profesional, dan berjarak dengan rakyat karena cenderung menempatkan dirinya sebagai bagian dari elite (Penders, 1984). Kondisi ini terus berlangsung hingga beberapa dekade kemudian. Pada tahun 1999, Bojonegoro pernah ditetapkan sebagai daerah dengan kemiskinan terparah se-Indonesia. Peringkat ini terus bertahan bahkan saat minyak dan gas (migas) ditemukan pada 2001 dan diekstrasi pada 2005. Selama kurun waktu tersebut, angka persentase kemiskinan memang terus menurun. Namun baru pada 2008, Bojonegoro berhasil keluar dari peringkat pertama daerah termiskin di Jawa Timur. Terhitung sejak 2008 hingga 2016, Bojonegoro menduduki peringkat ketiga daerah termiskin di Jawa Timur. Sesudahnya, Bojonegoro keluar dari peringkat 10 besar daerah termiskin di Jawa Timur.

Saat ini Bojonegoro dikenal sebagai salah satu daerah yang pemerintahnya paling maju dalam penggunaan data di Indonesia. Di saat pemerintah daerah lain di Indonesia belum memiliki kesadaran atas pengelolaan dan pemanfaatan data secara serius, Bojonegoro telah disebut sebagai daerah pertama yang menggunakan teknologi big data. Pemkab Bojonegoro menggunakan 53 aplikasi berteknologi big data untuk berbagai urusan pemerintahan dan tersebar di seluruh instansi. Tidak semua aplikasi tersebut bukan buatan Pemkab sendiri, namun seluruhnya dikelola oleh Pemkab secara langsung.

Tidak berhenti sampai di situ, Bojonegoro kemudian terkenal mendunia dengan penerapan revolusi data. Revolusi data merupakan bentuk keseriusan Pemkab dalam membuat sistem pendataan yang baik. Penerapan revolusi data tidak terlepas dari komitmen Pemkab Bojonegoro sebagai partisipan dalam Open Government Partnership (OGP) Subnational Government Pilot Progam. Prinsip terbuka yang dikampanyekan OGP mencakup tiga nilai yakni, partisipasi publik, akuntabilitas, dan transparansi. Revolusi data merupakan salah satu program yang dibuat khusus untuk mewujudkan tiga nilai OGP. Dihimpun dari dokumen Rencana Aksi Daerah (RAD) OGP Bojonegoro 2016, revolusi data adalah upaya pengumpulan hingga penyusunan seluruh data konvensional menjadi data tunggal yang terkumpul dalam sistem daring terintegrasi se-Indonesia. 
Kemajuan Bojonegoro dalam memulai revolusi data juga didorong oleh kepemimpinan Bupati Bojonegoro saat itu, Suyoto. Menurutnya, sistem data milik pemerintah yang tersedia hanya berbentuk statistik dan tidak cukup layak digunakan sebagai bahan dasar pembuatan kebijakan. Dalam meneliti masalah kemiskinan misalnya, data statistik hanya berbicara agregat kondisi masyarakat secara umum. Padahal, jika ingin berbicara kemiskinan dibutuhkan data granular, yakni data yang berisi informasi masing-masing individu secara mendalam. Pada saat yang sama, Suyoto juga merasakan ada beberapa masalah terkait pembangunan di daerahnya. Masalah tersebut tercermin dari pengalaman pemerintah kabupaten dari tahun ke tahun yang menghadapi gap expectation antara kinerja pembangunan yang dicapai dengan target yang direncanakan dalam RTRW, RPJMD, atau RPJPD Kabupaten Bojonegoro 2005-2025. Suyoto menjelaskan bahwa gap tersebut tercipta karena adanya perbedaan kondisi yang menjadi latar belakang penyusunan target pembangunan dengan kondisi riil saat implementasi target pembangunan. Masalah-masalah ini kemudian mendorong Suyoto untuk lebih tanggap pada kebutuhan akan DDPM di lingkungan Pemkab Bojonegoro.

Kepemimpinan Suyoto memainkan peranan penting dalam transformasi dari kondisi birokrat Bojonegoro yang disebut tidak profesional hingga kini menjadi salah satu yang paling maju dalam hal kepemilikan data dibanding pemerintah daerah lainnya di Indonesia. Sebelum memenangkan Pilkada Bojonegoro pada 2007 dan kemudian memimpin sebagai bupati di tahun itu, Suyoto merupakan dosen sekaligus rektor di Universitas Muhammadiyah Gresik. Latar belakangnya sebagai akademisi di bidang studi ilmu sosial dan politik bisa jadi membuat pendekatan Suyoto dalam menjalankan pemerintahan berbeda dengan bupati terdahulunya. Pasca dipimpin oleh Suyoto, banyak perubahan besar yang dilakukan terhadap wajah birokrasi di sana. Pemkab Bojonegoro tidak lagi menadi pemerintah yang sekadar hadir dan duduk di kantor setiap harinya, melainkan aktif melayani warganya.

Pada tahun pertama memimpin pada 2008, Suyoto memprioritaskan pembangunan infrastruktur di Bojonegoro. Setelah perekonomian Bojonegoro membaik, pada periode keduanya yakni 2013, Suyoto mulai berfokus menciptakan iklim pembangunan berkelanjutan yang terangkum dalam enam pilar berkelanjutan. Enam pilar pembangunan terdiri dari: (1) pilar ekonomi, (2) pilar lingkungan hidup, (3) pilar sosial/ modal sosial, (4) pilar kemandirian fiskal, (5) pilar pemerintahan yang bersih dan efektif, dan (6) pilar kepemimpinan transformatif. Tujuan khususnya menetapkan enam pilar pembangunan berkelanjutan ini untuk mengubah mental birokrat "bobrok" menjadi pekerja keras (Kasali, 2016). Suyoto juga yang menginisiasi pelaksanaan GDSC atas dasar kebutuhannya akan sebuah sistem pendataan di Bojonegoro. 


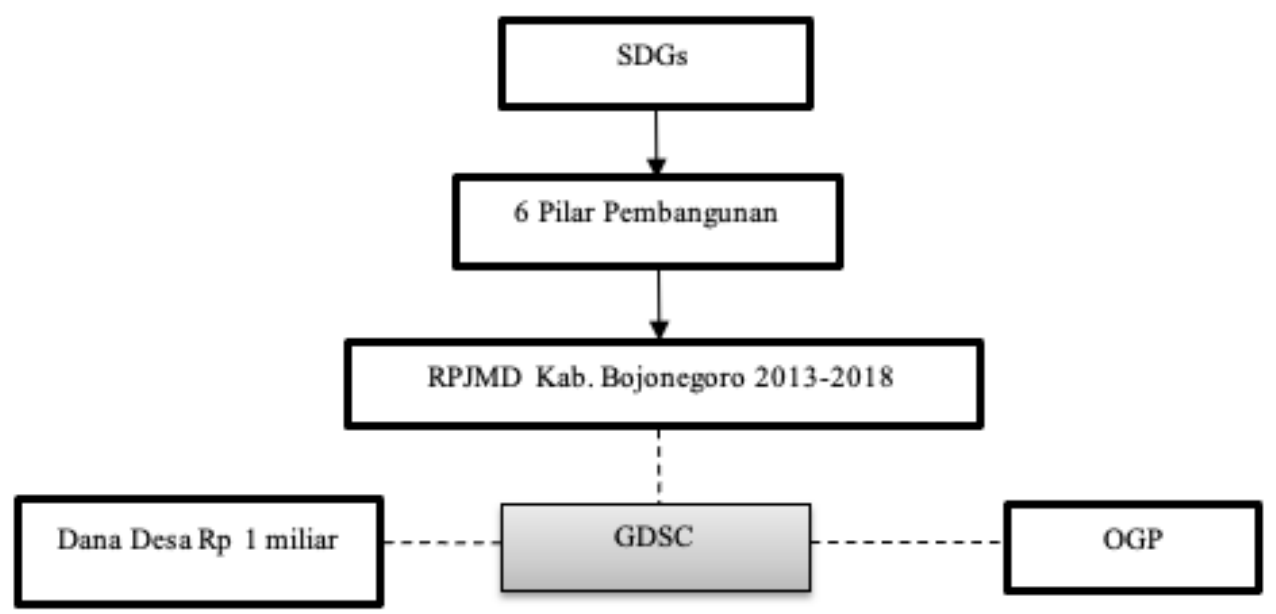

Bagan 1. Rangkaian Rancangan Pembangunan di Bojonegoro

Sumber: wawancara penulis dengan Bupati Bojonegoro, Suyoto, 18 Maret 2019.

Selain enam pilar pembangunan, kelahiran GDSC juga tidak terlepas dari perencanaan pembangunan Bojonegoro yang disusun berdasarkan Sustainable Development Goals (SDGs) atau Tujuan Pembangunan Berkelanjutan (TPB) dan tertulis melalui RPJMD. RPJMD 2013-2018 berisi target pembangunan Bojonegoro yang merupakan penjabaran dari enam pilar pembangunan yang dibuat Suyoto. Sementara enam pilar pembangunan merupakan turunan dari 17 poin Sustainable Development Goals (SDGs) yang telah dipilih sesuai prioritas kebutuhan Bojonegoro. Bersamaan dengan target-target pembangunan itu, ada momentum turunnya dana desa sekira Rp 1 miliar melalui UU Nomor 6 Tahun 2014 tentang Desa, sekaligus momentum terpilihnya Pemkab menjadi mitra percontohan Open Government Partnership (OGP).

Tujuan utama Suyoto menginisiasi GDSC adalah menciptakan sinergitas kerja pembangunan antarintansi agar penggunaan resources berupa anggaran, sumber daya alam, dan sumber daya manusia di Bojonegoro menjadi efektif. Untuk mencapai hal itu, GDSC mengusung pendekatan DDPM atau pembuatan kebijakan berbasis data. Data yang digunakan dalam bentuk granular. Data granular diperoleh berdasarkan data by name by address. Proses pendataan dilakukan oleh Kelompok Dasawisma berdasarkan indikator yang dibuat oleh Ketua Tim Penggerak PKK sekaligus istri Suyoto, Mahfhudoh. Terdapat 20 indikator pendataan GDSC yang secara garis besar meliputi dua masalah, yakni kesehatan dan pendidikan di level individu, pemerintah desa, dan lingkungan desa. Proses pendataan dilakukan di 419 desa dan 11 kelurahan yang tersebar di 28 kecamatan di Bojonegoro. Setelah pengumpulan data selesai dilakukan, data awal yang masuk dianggap sebagai titik nol kondisi desa. Titik nol ini menunjukkan masalah asli desa yang perlu diberi perhatian lebih oleh pemerintah desa. Pemerintah desa dan pemerintah kabupaten harus menjadikan data ini sebagai acuan dalam pembuatan kebijakan pembangunan. Kebijakan harus difokuskan untuk penyelesaian masalah yang terekam data.

Tepat saat dimulainya kepemimpinan Anna Muawanah, pengganti Suyoto sebagai Bupati Bojonegoro di tahun 2018, GDSC dihentikan pelaksanaannya. Anna membatalkan Perbup GDSC. Tidak 
hanya GDSC, Perbup Nomor 14 Tahun 2015 tentang Upah Umum Perdesaan juga dibatalkan olehnya. Kedua Perbup tersebut ditandatangani oleh Suyoto di era kepemimpinannya. Namun oleh Anna, kedua Perbup tersebut disebut cacat secara hukum karena tidak ada payung hukum di atasnya yang mengatur tentang hal serupa. Karena alasan ini, GDSC resmi tidak lagi dilaksanakan di Bojonegoro.

Setelah berhentinya dan hingga saat penelitian ini ditulis, belum ada penelitian yang secara jelas menjelaskan dampak positif langsung pelaksanaan GDSC pada pembangunan secara umum di Bojonegoro. Penelitian Sakti dan Rosdiana (2016) menjelaskan bahwa pelaksanaan GDSC tidak berpengaruh positif menurunkan angka kematian ibu dan bayi. Sementara penelitian Addina (2018) menjelaskan bahwa pelaksanaan GDSC berpengaruh positif pada peningkatan angka tuntas Open Defecation Free (ODF) di Bojonegoro. Artinya, GDSC berkontribusi dalam meminimalisir perilaku buang air besar sembarangan di desa-desa di Bojonegoro. Namun satu penelitian ini saja tidak dapat menjustifikasikan bahwa GDSC sukses dalam menerapkan DDPM. Addina hanya menjelaskan bahwa masing-masing stakeholder bekerja sama dalam mengerjakan program-program terkait penuntasan ODF.

Meskipun demikian, jika dikembalikan pada tujuan utama DDPM, ada yang salah dengan pelaksanaan GDSC. Pelaksanaan GDSC tidak sampai pada pemanfaatan data dalam pembuatan kebijakan di desa maupun di SKPD seperti yang diharapkan. Padahal, pemanfaatan data adalah inti utama DDPM. Nyatanya, SKPD lebih memilih menggunakan basis data miliknya sendiri atau dari kementerian, sementara desa merasa kesulitan memanfaatkan data GDSC sehingga memilih kembali pada cara lama, yakni berdasar hasil Musrembang. Hal ini mengindikasikan GDSC gagal memenuhi tujuan utama DDPM.

\section{HASIL DAN PEMBAHASAN}

\section{Memotret Kondisi Desa dalam Data GDSC}

Tabel 1. Mekanisme Pelaksanaan GDSC

\begin{tabular}{|l|l|l|}
\hline $\begin{array}{l}\text { Rancangan } \\
\text { Pelaksanaan }\end{array}$ & $\begin{array}{l}\text { Rincian Praktik } \\
\text { Pelaksanaan }\end{array}$ & Keterangan \\
\hline \multirow{3}{*}{$\begin{array}{l}\text { Pemotretan kondisi } \\
\text { riil di desa untuk } \\
\text { menentukan titik nol } \\
\text { seluruh indicator }\end{array}$} & $\begin{array}{l}\text { Merancang mekanisme } \\
\text { pelaksanaan dan } \\
\text { indikator GDSC }\end{array}$ & $\begin{array}{l}\text { Bupati Suyoto bersama Ketua Tim Penggerak PKK, Mahfhudoh } \\
\text { Suyoto menentukan parameter sehat dan cerdas, berikut 20 } \\
\text { indikator dan turunan sub-indikatornya. Indikator dan sub-indikator } \\
\text { ini menjadi acuan pengumpulan data di lapangan sekaligus acuan } \\
\text { penilaian kinerja pemerintah desa. }\end{array}$ \\
\cline { 2 - 3 } & Dembangun database & $\begin{array}{l}\text { Diskominfo membangun database Dasawisma sebagai wadah } \\
\text { penampung data yang dikumpulkan selama jalannya GDSC. }\end{array}$ \\
\cline { 2 - 3 } & Pelatihan Dasawisma & $\begin{array}{l}\text { BPMD, Bappeda, dan Diskominfo mengadakan pelatihan } \\
\text { pengumpulan sekaligus pengisian data ke dalam aplikasi database } \\
\text { untuk Kelompok Dasawisma. }\end{array}$ \\
\cline { 2 - 3 } & $\begin{array}{l}\text { Terjun mengumpulkan } \\
\text { data }\end{array}$ & $\begin{array}{l}\text { Kelompok Dasawisma terjun mengisi data individu dari 5 KK yang } \\
\text { tinggal di samping kanan rumah dan 5 KK lainnya yang tinggal di } \\
\text { samping kiri rumahnya. Sementara pemerintah desa mengisi sisa } \\
\text { data mengenai kondisi lingkungan dan keadaan desa yang tidak } \\
\text { dikumpulkan Kelompok Dasawisma. }\end{array}$ \\
\hline
\end{tabular}




\begin{tabular}{|l|l|l|}
\hline \multirow{2}{*}{$\begin{array}{l}\text { Penetapan target dan } \\
\text { rencana desa }\end{array}$} & $\begin{array}{l}\text { Input data ke dalam } \\
\text { database }\end{array}$ & $\begin{array}{l}\text { Kelompok Dasawisma dan Pemerintah desa menyerahkan data } \\
\text { yang telah diiisi pada Wali Data desa. Wali Data kemudian meng- } \\
\text { input data ke dalam aplikasi Dasawisma. }\end{array}$ \\
\cline { 2 - 3 } & $\begin{array}{l}\text { Menetapkan target dan } \\
\text { rencana prioritas } \\
\text { pembangunan }\end{array}$ & $\begin{array}{l}\text { Pemerintah desa bersama kecamatan mendiskusikan hasil } \\
\text { pendataan untuk menentukan masalah yang menjadi target prioritas } \\
\text { pembangunan desa. }\end{array}$ \\
\hline $\begin{array}{l}\text { Sinkronisasi gerakan } \\
\text { pemerintah pusat, } \\
\text { provinsi, kabupaten, } \\
\text { dan desa }\end{array}$ & Mendiseminasikan data & $\begin{array}{l}\text { Hasil pendataan dan rencana pembangunan desa kemudian } \\
\text { diteruskan pada BPMD dan Bappeda sebagai leading sector GDSC. } \\
\text { Selain itu, pemerintah desa wajib mempresentasikan hasil itu di } \\
\text { hadapan bupati bersama jajaran SKPD. Dalam forum presentasi itu, } \\
\text { rencana pembangunan desa akan diberikan masukan dan ditinjau } \\
\text { ulang agar tidak terjadi tumpang tindih kewenangan maupun } \\
\text { masalah legal formal di masa depan. }\end{array}$ \\
\hline $\begin{array}{l}\text { Sistem pelaporan, } \\
\text { monitoring, dan } \\
\text { evaluasi berbasis IT }\end{array}$ & Evaluasi data & $\begin{array}{l}\text { Bojonegoro Institute sebagai LSM membantu validasi data dengan } \\
\text { cara mencocokkan data satu sama lain. }\end{array}$ \\
\hline $\begin{array}{l}\text { Reward and } \\
\text { punishment }\end{array}$ & $\begin{array}{l}\text { Pemberian penghargaan } \\
\text { pada desa dengan } \\
\text { kinerja terbaik }\end{array}$ & $\begin{array}{l}\text { Pemerintah kabupaten memberikan penghargaan pada desa yang } \\
\text { dinilai mampu menuntaskan indikator paling banyak dalam jangka } \\
\text { waktu yang ditentukan. }\end{array}$ \\
\hline
\end{tabular}

Berbagai pihak mulai internal hingga eksternal Pemkab seperti LSM dilibatkan dalam proses pelaksanaan GDSC. Namun, Suyoto yang paling dominan terlibat sejak perencanaan hingga pelaksanaan GDSC. Seperti yang telah diceritakan sebelumnya, program ini diinisiasi oleh Suyoto. Selanjutnya, ia bersama istrinya sekaligus Ketua PKK, Mahfhudoh Suyoto, merancang indikator sekaligus setiap langkah pelaksanaan GDSC. Keduanya mengadaptasi Global Indicator Frameworks yang digunakan sebagai indikator SDGs atau TPB. Bedanya, Mahfhudoh dan Suyoto hanya berfokus di dua hal, yakni kesehatan dan pendidikan di level individu, pemerintah desa, dan lingkungan desa. Mahfhudoh membuat indikator-indikator pendataan berdasarkan masalah yang menurutnya umum terjadi di Bojonegoro. Mahfhudoh mengumpulkan sekitar 300 masalah penyebab terhambatnya pembangunan di sana. 300 masalah ini kemudian dipetakan berdasarkan bidang masalahnya. Hasilnya, secara garis besar masalah yang terjadi ada di bidang kesehatan dan pendidikan yang terjadi di level individu, institusi, sekaligus lingkungan desa.

Disetujuinya indikator GDSC yang dibuat oleh Suyoto dan Mahfhudoh, maka dapat dipahami juga bahwa proses sekaligus output pembangunan yang dilakukan di Bojonegoro, terutama di desa-desa berjalan ke arah yang dikehendaki keduanya. Proses yang menurutnya ideal adalah proses yang memanfaatkan data sebagai basis pengambilan keputusan. Sementara output kebijakan yang dianggap ideal oleh Suyoto tercermin dalam 20 indikator GDSC. Data dan indikator-indikator pembangunan lain yang sudah ada, dianggap tidak sesuai dengan ukuran ideal Suyoto sehingga harus diganti melalui implementasi GDSC.

Meskipun di atas telah dijelaskan bahwa pelaksanaan GDSC berjalan sesuai rencana, ada tiga hal yang mengindikasikan ketidaksiapan pelaksana dalam menjalankan DDPM. Pertama, database Dasawisma yang dibangun Diskominfo sebenarnya tidak memadai untuk digunakan sebagai infrastruktur DDPM. GDSC menggunakan data granular sebagai basis pengetahuan yang digunakan dalam pembuatan kebijakan publik. Data granular merupakan data yang lebih kompleks dibanding data 
agregat. Jika data agregat adalah kumpulan informasi, data granular adalah detail-detail kecil dari informasi tersebut. Karena itu, data granular justru berpotensi menangkap hal yang tidak bisa ditangkap data agregat sehingga bisa menghasilkan informasi yang lebih kompleks dibanding data agregat. Untuk memperoleh informasi kompleks ini, dibutuhkan alat yang mumpuni untuk membaca data granular sebab kemampuan manusia biasa saja tidak cukup untuk menangkap kompleksitas data.

Alat yang umumnya digunakan saat ini berupa teknologi big data yang bisa menampung data dalam jumlah lebih besar hingga tidak terhingga, lebih variatif, dan lebih cepat dibanding pangkalan data biasa. Dalam level lebih lanjut juga dibutuhkan keterlibatan data scientist, yakni profesional yang ahli mengolah data kompleks. Nyatanya, dalam kasus Bojonegoro selama penyelenggaraan GDSC belum ada infrastruktur semacam big data yang mampu menggali nilai data granular secara mendalam. Proses validasi data pun masih dilakukan secara manual dengan bantuan Bojonegoro Institute karena aplikasi Dasawisma yang tersedia tidak mampu mendeteksi kesalahan atau kejanggalan data. Karena keterbatasan itu, data GDSC yang telah digali secara detail juga pada akhirnya menjadi data agregat biasa saja karena tidak dapat diketahui hubungannya satu sama lain. Padahal salah satu hal yang melatarbelakangi pelaksanaan GDSC adalah keinginan Suyoto untuk memiliki sistem data granular di tengah data-data agregat milik instansi pemerintahan lain.

Kedua, kualitas sumber daya manusia pelaksana juga tidak mumpuni untuk melaksanakan DDPM. Temuan ini berawal dari hasil validasi Bojonegoro Institute (BI) atas data GDSC yang menunjukkan ketidaksesuaian data GDSC satu sama lain. Bagi Kelompok Dasawisma yang mengumpulkan data GDSC di lapangan, tidak ada insentif atau manfaat langsung yang didapatkannya, sehingga tidak ada motivasi bagi mereka untuk serius mengumpulkan data. Ditambah lagi, Kelompok Dasawisma tidak memiliki pengetahuan dan kemampuan yang sama dengan pendata profesional. Anggota Kelompok Dasawisma sebagian besar merupakan Ibu-Ibu anggota PKK yang sehari-hari merupakan ibu rumah tangga dengan pendidikan formal terakhir adalah SMA. Mereka tidak akrab dengan penggunaan komputer apalagi penggunaan aplikasi seperti Dasawisma. Meski telah diberi pelatihan khusus, namun kemampuan anggota Dasawisma dalam menggunakan komputer terbatas di level pemula, belum sampai di pengisian kolom-kolom data melalui aplikasi.

Ketiga, pemerintah desa sebagai pelaksana sekaligus objek GDSC sendiri tidak memiliki kemampuan untuk mengolah dan memanfaatkan data dalam pembuatan kebijakan. Data yang dikumpulkan berupa angka-angka kuantitatif. Padahal, perangkat desa tidak memiliki kemampuan mengubah data kuantitatif tersebut menjadi insight yang dibutuhkan dalam pembuatan kebijakan. Karena tidak bisa mengelola data dengan baik, akhirnya data GDSC menjadi tidak terurus begitu saja. Pemanfaatan bahkan penyimpanannya menjadi tidak jelas. Dalam kasus Desa Plesungan dan Pejambon misalnya, pada akhirnya data GDSC tidak digunakan sebagai rujukan utama penentuan prioritas. Penentuan prioritas pada akhirnya dikembalikan pada musyawarah warga.

Tiga hal ini mengindikasikan bahwa GDSC gagal memenuhi standar teknis DDPM meski telah dijalankan sesuai prosedur pelaksanaannya. Akibat dari tiga masalah ini, GDSC berhenti hanya di tahap 
pengumpulan data. Pemanfaatan data dalam pembuatan kebijakan arah pembangunan desa justru tidak terjadi. Apa yang ditunjukkan GDSC melalui perencanaannya memang telah mengarah pada munculnya kesadaran Suyoto sebagai inisiator GDSC tentang pentingnya teknik dan instrumen yang tepat dalam pembuatan kebijakan. Pelaksanaannya pun melibatkan partisipasi banyak pihak. Namun, partisipasi banyak pihak ini tidak dibarengi dengan kesiapan dan kemampuannya, sehingga praktik GDSC justru tidak sampai pada pembuatan kebijakan publik yang merefleksikan adanya sensitivitas merespon realitas masalah desa yang ditunjukkan dengan data.

\section{Berebut Data, Berebut Menentukan Pembangunan di Desa}

GDSC lahir, terlaksana, hingga berakhir berkat partisipasi aktor-aktor yang terlibat di dalamnya. Di balik partisipasi aktor-aktor ini, dapat dijelaskan bagaimana GDSC menjadi arena beroperasinya kekuasaan aktor tersebut. Penjelasan akan berfokus pada relasi Suyoto dengan pelaksana GDSC yang terdiri dari Kelompok Dasawisma, pemerintah desa, serta perangkat daerah yang terdiri dari badan dan dinas internal Pemkab. Suyoto diletakkan sebagai tokoh utama dalam penjelasan ini sebab Suyoto merupakah tokoh sentral yang mendorong kelahiran GDSC sekaligus menjadi salah satu alasan berakhirnya GDSC.

Tidak dipungkiri bahwa pelaksanaan GDSC dapat terjadi karena partisipasi masing-masing pihak yang aktif memenuhi tanggung jawabnya. Di saat yang sama, GDSC merupakan program Suyoto yang sifatnya top-down sejak kelahirannya. Suyoto yang paling dominan menentukan tujuan, mekanisme, hingga detail seperti indikator. Indikasi bahwa GDSC adalah program yang sifatnya topdown juga terbukti dalam pelaksanaannya. Pelaksanaannya menemui tiga masalah teknis yakni, (1) infrastruktur database yang tidak mampu mengolah data granular sehingga data GDSC menjadi data biasa; (2) Kelompok Dasawisma tidak memiliki motivasi dan kemampuan untuk mengumpulkan data dengan baik; (3) Pemerintah desa juga tidak memiliki kemampuan untuk mengelola data. Ketiga masalah ini merupakan masalah yang sifatnya teknis dan terjadi di tingkat pelaksana. Artinya, perancangan GDSC di awal tidak mengantisipasi ketidaksiapan dan ketidakmampuan pelaksana. Logikanya, jika GDSC bersifat bottom-up, tentu hal semacam ini telah diantisipasi sejak awal oleh pelaksana sendiri.

Terlebih, pada akhirnya terbukti bahwa pelaksanaan GDSC hanya sekadar terjadi untuk memenuhi tahapan prosedur pelaksanaannya. Sementara, tujuan akhir DDPM justru tidak tercapai. Pemerintah desa memilih untuk tidak menggunakan data dalam penentuan arah kebijakan pembangunan di desa. Data GDSC pun hingga kini tidak jelas penyimpanannya. Artinya, ada indikasi bahwa pelaksana hanya sekadar memenuhi tanggung jawabnya, tetapi tidak memiliki kesadaran akan pentingnya memanfaatkan data dalam pembuatan kebijakan. Bagi pelaksana, GDSC hanya tentang pemenuhan tanggung jawab, bukan kebutuhan akan pelaksanaan DDPM. 


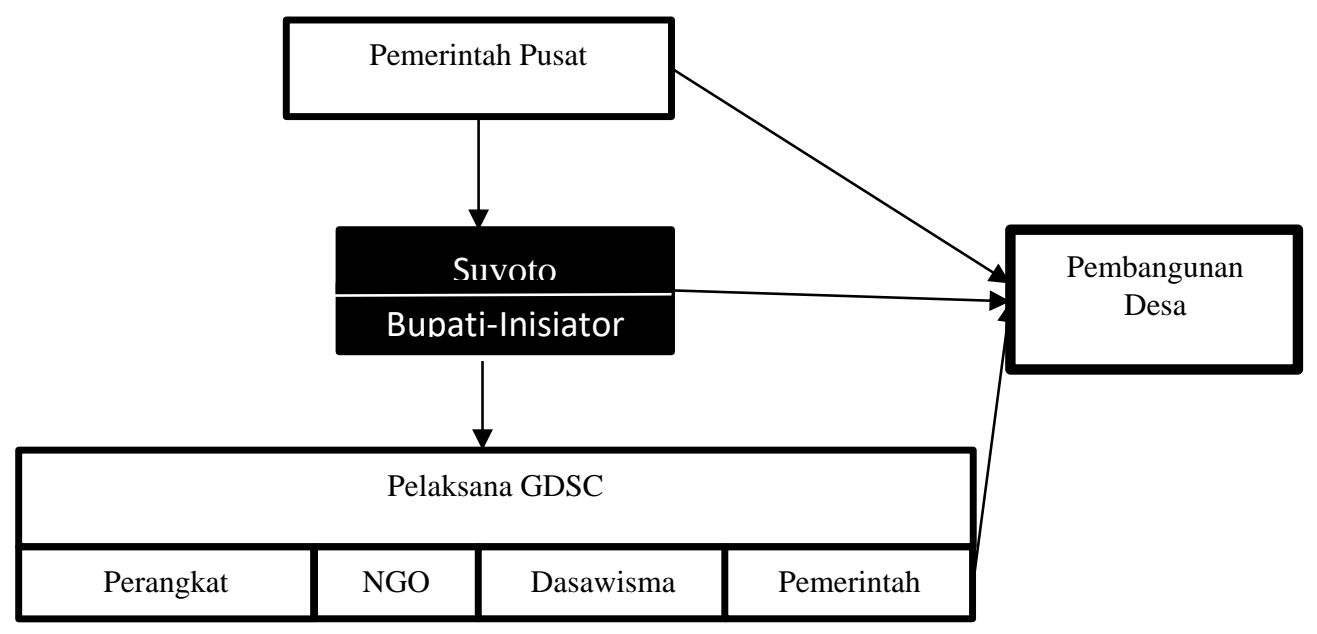

Bagan 2. Relasi Aktor GDSC

Melalui bagan tersebut, dapat dijelaskan hal yang menyebabkan kepatuhan pelaksana GDSC dalam memenuhi prosedur pelaksanaan GDSC, sekaligus tidak patuhnya dalam memanfaatkan data GDSC. Bagan ini menggambarkan relasi antaraktor yang terlibat dalam pembangunan di desa di Bojonegoro. Setidaknya, pembangunan di sebuah daerah melibatkan pemerintah pusat, pemerintah daerah, pemerintah desa, hingga instansi non-pemerintah. Masing-masing memiliki peran berbeda, namun berdasarkan hierarki Sistem Perencanaan Pembangunan Nasional, masing-masing instansi pemerintah terhubung satu sama lain melalui dokumen perencanaan pembangunan nasional.

Berdasarkan Sistem Perencanaan Pembangunan Nasional, pemerintah pusat jelas memiliki kekuasaan paling besar dalam mengatur jalannya pembangunan di Indonesia. Pemerintah daerah di level provinsi dan kabupaten memiliki kewajiban untuk mengacu dokumen perencanaan pembangunan nasional. Hal ini yang menjelaskan mengapa indikator-indikator GDSC yang dibuat oleh Suyoto memiliki banyak kesamaan dengan indikator dari basis data milik instansi lain. Masing-masing merujuk pada dokumen RPJMN yang sama. Di saat yang sama, Suyoto sebagai kepala daerah memiliki kepentingan untuk mengatur pembangunan di daerahnya melalui GDSC. Hal ini dibuktikan melalui dua hal. Pertama, kemunculan kebutuhan akan DDPM maupun GDSC hanya berasal dari Suyoto dan tidak muncul di level pelaksana. Kedua, melalui GDSC, Suyoto sedang 'membajak' Sistem Perencanaan Pembangunan Nasional (top-down) dengan mengarahkan perangkat daerah untuk membuat kebijakan berdasarkan data GDSC yang muncul dari desa (bottom-up).

Penjelaasan itu menjawab pertanyaan mengapa perangkat daerah di satu sisi patuh pada Suyoto, namun di sisi lain menolak menggunakan data GDSC. Bagi perangkat daerah sebagai perangkat pembantu bupati, urusannya hanya mengikuti mandat bupati. Secara struktural mereka di bawah kewenangan dan kekuasaan bupati. Ditambah lagi, Suyoto cukup cerdik menggunakan sumber dayanya sebagai bupati, melembagakan GDSC melalui Perbup Nomor 47 Tahun 2014, sehingga pelaksana tidak bisa menghindar dari GDSC. Namun di sisi lain, Sistem Perencanaan Pembangunan Nasional membentuk logika perangkat daerah sebagai bagian internal Pemkab untuk patuh ke atas, bukan ke 
bawah. Perangkat daerah bertugas menyukseskan pembangunan nasional, bukan merespon masalah di desa yang ditunjukkan data seperti yang diinginkan Suyoto melalui GDSC.

Berbeda dengan keperluan dinas dan badan internal Pemkab maupun Suyoto, pemerintah desa justru memiliki keterikatan dengan Pemkab sekaligus pemerintah pusat. Berdasarkan UU Nomor 6 Tahun 2014, pemerintah desa wajib membuat RPJMDes yang disesuaikan dengan RPJMD Kabupaten. Alih-alih pemerintah kabupaten yang menyesuaikan data berdasarkan kondisi desa seperti yang diharapkan GDSC, justru pemerintah desa yang harus menyesuaikan target pembangunannya dengan Pemkab. Ada ketimpangan relasi antarpelaksana GDSC dengan Suyoto sebagai inisiator GDSC, sekaligus Bupati Bojonegoro. Suyoto memiliki kewenangan sebagai bupati untuk membuat pelaksana GDSC patuh pada pelaksanaan GDSC. Sementara pelaksana GDSC tidak memiliki kuasa untuk tidak patuh memenuhi tanggung jawab pelaksanaan GDSC. Di saat bersamaan, regulasi tentang Sistem Perencanaan Pembangunan Nasional berhasil membentuk logika perangkat daerah untuk berani mengacuhkan data GDSC. Melalui regulasi itu, posisi perangkat Pemkab ditegaskan hanya berurusan dengan instansi vertikal ke atas, bukan ke bawah.

\section{KESIMPULAN}

Penerapan DDPM melalui GDSC berjalan sesuai prosedur pelaksanaan yang ditetapkan oleh Suyoto di awal. Masing-masing pelaksana memenuhi tanggung jawab yang tertulis dalam Peraturan Bupati Nomor 47 Tahun 2014 tentang GDSC. Terlepas dari kepatuhan pelaksana, ada tiga masalah teknis yang ditemui dalam pelaksanaan GDSC. Masalah pertama, yakni infrastruktur database yang tidak mampu mengolah data granular sehingga data GDSC menjadi data biasa. Kedua, kelompok Dasawisma tidak memiliki motivasi dan kemampuan untuk mengumpulkan data dengan baik sehingga hasil pendataannya tidak valid. Terakhir, pemerintah desa juga tidak memiliki kemampuan untuk mengelola data. Akibat lanjutan dari tiga masalah ini, pemanfaatan data dalam pembuatan kebijakan arah pembangunan desa justru tidak terjadi.

Masalah teknis yang hanya terjadi di level pelaksana disebabkan perencanaan GDSC yang cenderung top-down. Perencanaannya lebih banyak didominasi oleh Suyoto, bupati sekaligus inisiator GDSC. Kendala teknis di level pelaksana tidak diantisipasi dalam perencanaannya. Malah, kebutuhan akan data GDSC juga tidak muncul di level pelaksana, sebab bagi mereka kebutuhan akan data telah tercukupi oleh basis data yang disediakan kementerian dan BPS. Akibatnya saat data GDSC telah tersedia pun, pelaksana GDSC sendiri memilih tetap menggunakan data dari kementerian yang sebelumnya telah mereka gunakan.

Lebih dari itu, pembangunan di Indonesia secara umum maupun di desa secara khusus, melibatkan campur tangan banyak pihak. Merujuk pada Sistem Perencanaan Pembangunan Nasional, perangkat daerah sebagai bagian dari Pemkab bertugas menyukseskan pembangunan nasional, bukan merespon masalah di desa yang ditunjukkan data seperti yang diinginkan Suyoto melalui GDSC. Dari sini terlihat bahwa ada perbedaan logika tentang perencanaan pembangunan antara Suyoto dengan 
perangkat daerah sebagai pelaksana GDSC. Pun yang terjadi antara Suyoto dengan pemerintah desa, merujuk pada UU Nomor 6 Tahun 2014, pemerintah desa wajib membuat RPJMDes yang disesuaikan dengan RPJMD Kabupaten.

Perbedaan logika perencanaan pembangunan antara Suyoto dengan perangkat daerah dan pemerintah desa membuat data GDSC tidak terurus dan tidak dimanfaatkan dalam pembuatan kebijakan. Perangkat daerah memiliki kepentingan untuk menyukseskan pembangunan nasional, sementara pemerintah desa sendiri harus menyesuaikan target pembangunannya dengan Pemkab, terlepas apapun yang dikatakan oleh data GDSC tentang kondisi desanya. Bagaimanapun, bagi perangkat daerah sebagai perangkat pembantu bupati, kewajibannya mengikuti mandat bupati. Ditambah lagi, Suyoto menggunakan sumber dayanya sebagai bupati melembagakan GDSC melalui Perbup Nomor 47 Tahun 2014. Besarnya kekuasaan dan kewenangan Suyoto sebagai bupati dibanding pelaksana GDSC, membuat pelaksanaan GDSC tetap berjalan meski pelaksana sendiri tidak merasakan kebutuhan akan data GDSC.

\section{DAFTAR PUSTAKA}

Easton D (1956) A Systems Analysis of Political Life. New York: John Wiley.

Esty D \& Rushing R (2007) The Promise of Data Driven Policy Making. Issues in Science and Technology.

Hulme M (2018) How Can Data Science Contribute to Developing Evidence Based Policy. CSaP's Continuing Policy Fellows.

Kasali R (2016) Curse to Blessings: Transformasi Bojonegoro Melawan Kutukan Alam. Mizan.

Kindornay S, Bhattacharya D, \& Higgins K (2016) Implementing Agenda 2030: Unpacking the Data Revolution at Country Level. Centre For Policy Dialogue.

Lebied M (2017) Examples of Big Data Analytics in Healthcare That Can Save People.

McAfee A \& Brynjolfsson E (2018) Machine. Platform, Crowd: Harnessing Our Digital Future. W. W. Norton Company

Palangkaraya A, Webster E, \& Cherastidtham I (2012) Evidence Based Policy: Data Needed for Robust Evaluation of Industry Policies. Melbourne Institute of Applied Economic and Social Research.

Penders CL (1984) Bojonegoro 1900-1942: A Story of Endemic Poverty in North-East Java. Gunung Agung.

Santoso P, Hanif H, \& Gustomi R (2004) Menembus Ortodoksi: Kajian Kebijakan Publik. Yogyakarta: Fisipol UGM.

Sakti IP \& Rosdiana W (2016) Implementasi Program GDSC di Desa Bulu Kecamatan Balen Kabupaten Bojonegoro: Studi Pada Parameter Sehat Indikator AKI dan AKB.

Addina, RZ (2018) Analisis Pelaksanaan Program Open Defecation Free dan Peran Stakeholders di Kabupaten Bojonegoro. Dari http://researchgate.net/ 